\title{
The impact of nation branding campaigns on country image. Case Study: Romania
}

\author{
Anca-Georgiana ANDREI \\ The Bucharest University of Economic Studies, Bucharest, Romania \\ anca.georgiana.andrei@gmail.com
}

\begin{abstract}
The purpose of this paper is to analyze how a nation branding campaign can influence the image of a country and to highlight its positive or negative impact on industries such as tourism and on people's perception. In order to accomplish this objective, Romania was taken as a case study. Five of the most important nation branding campaigns in Romania, after 1989, were examined in comparison, analyzing the same indicators. In the end, the paper shows that if nation branding campaigns do not follow a long-term strategy with all actors involved in the process, its impact in country image may be rather negative.
\end{abstract}

Keywords: nation branding, country image, nation branding campaign, globalization, comparative analysis, SWOT.

Please cite the article as follows: Andrei, A.G. (2017), "The impact of nation branding campaigns on country image. Case study: Romania", Management \& Marketing. Challenges for the Knowledge Society, Vol. 12, No. 2, pp. 222-236. DOI: 10.1515/mmcks-2017-0014.

\section{Introduction}

In the context of globalization, from 1990, the phenomenon called nation branding started to present more and more interest for researchers as it was considered one of the ways of creating competitive advantage for the countries (Andrei, 2017).

At the beginning of 1990, Romania was perceived as a communist country dominated by an antidemocratic totalitarian regime and the image of Romania outside the country was associated a lot with Ceausescu, poverty and communism. (Dolea, 2015). All these can be considered stereotypes. Lustig and Koester (1999) argue that most stereotypes are exaggerated and show rather the negative side of a place, ignoring what is positive. In order to replace these stereotypes, Romanian public institutions realized that nation branding campaigns are necessary and that the country has to improve its image.

This paper presents briefly how did the process of nation branding developed in five different campaigns which had the same main purpose: improve the image of Romania. In the end, the article shows the impact of every campaign, but also the impact of all five together. A SWOT analysis is also a part of the conclusions and it has the role of emphasizing the strengths and weaknesses of the campaigns. Despite the limited scope of this investigation, the conclusions provide also a small general background which can be taken in consideration by researchers and professionals when elaborating strategies for nation branding campaigns. 


\section{Literature review}

The concept nation branding was first coined by Simon Anholt in 1996 and it developed very much during the last ten years. In 2005, it was listed as one of the most notable ideas of the year by the New York Times Magazine (Kaneva, 2011, p. 117).

More and more researchers started to focus on the idea that a country's brand can profoundly shape its economic, cultural and political destiny, as well as international competitiveness (Nicolescu, 2012). So, the place started to become more important than before (Amin and Thrift, 1994; Meyer and Gerschiere, 1999). The research in country marketing domain has been first focused on discussions about country image or reputation. Howard and Seth (1968) are the first who tried to explain this notion. Nation branding concept was coined first by Simon Anholt in 1996, who has also become most prolific author on this topic (Dinnie, 2008). Anholt (2007, 2009, 2010) described in his papers the entire process of nation branding, coming at the same time with innovative theories about how to measure nation branding.

Marketing experts are often highlighting the difference between country image/reputation and nation brand, an aspect also very important for understanding the subject of this paper. "The difference between country image/reputation and nation brand is that the image or reputation of a country can be created without any concrete actions, while nation brand is the image of a country as a result of the efforts made by the nation in this purpose. So, nation brand is more than country image, it is a country image influenced consciously and directed in a favorable direction for the country (Nicolescu, 2008, p. 32).

Another relevant author for this domain is Wally Olins $(1999,2003,2008)$ who has also analyzed Romania's country image and was ready to build a new nation brand for 1 million dollars a year (Gandul, 2007). Olins remarked, when making this offer to the Romanian authorities that "perceptions are much worse than reality; reality is better and improves every day, but perceptions are bad and they don't improve at all" (Gandul, 2007). Nicolescu (2012) also concluded that "as far as Romania is concerned, there is the need for creating and repositioning of its image abroad". Dolea $(2009,2015)$ analyzed Romania's nation branding campaigns and came to the conclusion that the way those were conceived showed a lack of research in this field particularizing on Romania. Aronczyk (2013), Dinnie (2008) and Kaneva $(2011,2012)$ focused their researches more on determined nation branding campaigns from different countries, practically they based a lot their work on case studies.

Identifying an existent natural identity (Nicolescu et al., 2008) could be useful for country branding and sometimes identifying facts in a regional identity in our case European identity can be very relevant (Diaconescu et al., 2007). Kaneva $(2011,2012)$ chose Romania as subject for her papers and stated that "the authors argue that the government's efforts are predestined for failure as they do not engage the wide support of the Romanian population and, in the end, are aimed at 
producing narratives that satisfy the desires of a Western gaze more than anything else."

\section{Research methodology}

Taking in consideration the researcher's conclusions mentioned above, the objective of this paper is to provide a general background of the current situation of Romania's brand and to draw some conclusions which could be used by experts in nation branding when elaborating new strategies for Romania's branding campaigns.

In order to attain this objective, I compared five of the most important nation branding campaigns, analyzing the next indicators:

$>$ Agent - who launched the campaign;

$>$ Purpose of the campaign;

$>$ Cost of the campaign;

$>$ Website of the campaign;

$>$ Number of foreign tourist attracted one year after the nation branding campaign;

$>$ General view of internal media (tone of coverage) taking in consideration first 50 Romanian articles related to the analyzed campaign - qualitative approach;

$>$ General view of international mass media (tone of coverage) taking in consideration first 50 Romanian articles related to the analyzed campaign in English or French - qualitative approach; despite the limited research of this indicator, it gives a relevant overview of the media perception;

$>$ Relevant evaluation provided by the initiating institution which provides data regarding the consequences of the campaign.

Monitoring the international media can be an effective way of understanding the image of a country (Anholt 2007, 2009), that's why I have also used a qualitative approach in my analysis. Based on these indicators, a SWOT analysis will show the conclusions of this paper. Before withdrawing relevant data based on numbers, it is first necessary to make a summary of the five branding campaigns, starting with the description of the events which determined Romanian authorities to invest in branding.

This short presentation is necessary in order to better understand how certain actions can have a very big impact on country image, whether they are part of a campaign of institutions, whether they are spontaneous actions.

\section{The context before branding Romania}

In order to understand the process of branding Romania and branding a nation in general, it is necessary to know first important elements of its past because the can represent strong stereotypes, which should be taken in consideration when building a campaign. 
The Romanian historian Neagu Djuvara emphasized that 50 years of communism broke Romanians' soul and that first thing that can be done for branding this nation is to write the correct history (Sorin, 2015). Starting from this idea, a brief context of Romania's position at international level will be presented. During the first months of 1990, right after the fall of communism, "more international reporters came to Bucharest in order to write about the enthusiasm of a country that has just changed its political regime and gained its freedom. But they faced a different reality than expected: thousands of mine workers were violently marching on the streets of Bucharest, shouting "Death to the intellectuals" and "We work, we don't think", and causing casualties and death" (Dolea, 2015, p. 86).

The entire country and the Occident found out from the stories of Romanian and international media not only about these events, but also about several social problems which were not made public previously: the existence of many children with disabilities, institutionalized children and orphanages with insufficient funding and very hard conditions to live in. After all these, Romania started to be associated with negative stereotypes and gained bad reputation (Dolea, 2015).

So the end of communism did not succeed to replace automatically the existent attributes of national identity with a new story politically convenient (Verdery, 1991).

What had actually happened did not open up a completely new debate on national identity but took the lid off of one that had been boiling underneath (Kaneva, Popescu, 2011).

The national media and the Romanian opinion leaders criticized the international media for obsessively circulating these images and thus consolidating these clichés, although Romania was not the only country facing this kind of problems. They also criticized the Government for the lack of reaction (Dolea, 2015). That lack of reaction almost 30 years ago, let these negative stereotypes to become so strong that even Hillary Clinton mentioned them in her presidential campaign from 2008 against Obama and 2016 against Trump (Dinu, 2016), giving Romania as a bad example - a country where abortion was forbidden although the orphanages were overpopulated and offered bad conditions.

Also in 1990, another event created bad reputation for Romania. In the international media, it was promoted the fact that a group of Roma people, originating from Romania had eaten stolen swans from a lake in Vienna. Although this information has never been confirmed, it created a stereotype that has impact also today and the Government should have taken action in order to decrease its impact (Padurariu, 2015).

All those events promoted in the international media deteriorated Romania's image, reason why Romanian government started to think about a nation branding campaign.

\section{Brief presentation of Romanian branding campaigns after 1989 Eternal and Fascinating Romania}


Agent. In 1994, the idea of branding Romania had become one of the main preoccupation of the authorities. So in 1996, Romanian Government with the support of the Romanian Presidency launched the campaign Eternal and Fascination Romania.

Its purpose was to change/improve Romania's image abroad.

The cost was of 5.97 million dollars (5.61 million euro) and it was paid by the sponsor Bancorex, a former Romanian Bank, which was liquidated in 1999 and absorbed later by Romanian Commercial Bank (BCR).

Description. The branding campaign consisted in a 513 photos album with texts translated in French, English, Arab, Spanish, Japanese, Italian and Romanian. It is important to mention that the original version was in French and not in Romanian. The experts considered that the messages were not well conceived and that that there were not strong enough in order to reach the audience. The album should have been printed in 97000 copies which should have been sent in 96 countries. The company which was dealing with this task was French and belonging to Adrian Costea, former advisor of Romania's president, Ion Iliescu. But until the end of contract, march 1998, only 10,000 copies from which 4200 were sent in Romania. First 1,333 were considered special edition, and there were sent as protocol to different Romanian personalities.

It had no website and no continuation.

There was no evaluation of this branding campaign of the Romanian authorities, but shortly after the end of it a corruption scandal covered the front page of all papers. Adrian Costea was accused by the French prosecutors that he that would have diverted about 50 million Francs (7.6 million euros) coming from business with the Romanian state, using the money for his own benefit of other officials and also to fund the 1996 campaign of former President Ion Iliescu (19891996 and 2000-2004). Album Eternal and Fascinating Romania was part of the subject of investigation. In 2008, Adrian Costea was sentenced to Paris, to 3 years in prison and a fine of 150,000 .

In conclusion, the purpose of this campaign was to improve Romania's image abroad, but it actually made it worse. This idea is withdrawn taking in consideration the indicators mentioned above.

Before the campaign, in 1994, Romania received 856,136 foreign tourists and after the end of the campaign, in 1999 the number decreased to 832,775 (INSSE, 2017).

From the tone coverage of media point of view, I analyzed 50 articles from the Romanian press and 50 articles from the International Press. They all had a negative tone and they were all focused on the corruption scandal. At the same time, there were all mentioning the name Adrian Costea. It is also important to mention, that 49 out of 50 international articles were in French.

Also, at present the campaign Eternal and Fascinating Romania is associated with the corruption scandal, a proof to support this is the lawsuit filed by Romanian Commercial Bank which replaced Bancorex, to recuperate the 5,97 million dollars. (Digi24, 2016). 


\section{Romania, Simply Surprising}

Agent. In 2001, the Directorate General for Tourism Promotion launched a call for a new nation branding campaign. The auction for this project was considered by the Romanian media "secret" and based on political relations (Capital, 2004). The contract was obtained by the PR agency Ogilvy \& Mather.

The slogan was Romania, simply surprising and its purpose was to attract foreign tourist. The cost was considerable, 20 million dollars (18,692,000 euro)

Description. In 2004, the agency launched the nation branding campaign which was actually an advertising campaign focused on commercial spots on international television (Euronews, Eurosport, Discovery, CNN, BBC) and banners in print newspapers. Although it had a correct media planning, it was broadcasted on the international televisions during holiday period. In the end, the campaign was abandoned without the publication of an evaluation (Nicolescu, 2008).

The campaign was later criticized by the World Tourism Organization for not communicating the essence of Romania. According to the UNWTO team of experts, Romania had no strong or clear image in the marketplace and the destination brand sent mixed signals (Sepi, 2013).

The campaign had no website and no evaluation was shown public by authorities.

Regarding the number of foreign tourists, the number increased. In 2000, before launching the idea of the new campaign, the number of foreign tourist was 867,024 and in 2005, one year after the campaign almost doubled, 1,429,911 (INSSE, 2017). There are not relevant data regarding the money spent by the tourists at that time.

From the tone coverage of media point of view, the analyzed articles related to the slogan of this campaign are not necessary related to the nation branding campaign, but to a lot of other subjects. This is applied both for Romanian articles and international articles.

However, the general tone related the campaign is rather negative. The international media treated the subject more basing on World Tourism Organization Opinion, and the Romanian one focused on the contract obtained in a not transparent way by PR agency Ogilvy\&Mather.

\section{Fabulospirit}

Agent. In 2006, Romanian Minister of Foreign Affairs (MAE) launched a new nation branding campaign with a brand new purpose. According to MAE press release, Fabulospirit will „shape the image of Romania as a new EU member, emphasizing the spiritual dimension of the Romanian people"(Fabulospirit, 2008).

The cost of the campaign supposed to be 5 million euro.

Description. The concept was launched in 2007, but again the way that the contract was attributed to an agency was the main subject for the Romanian media. Corina Vințan, MAE spokeswoman argued then that she decided to choose the company Gav/Scholz \& Friends because the project manager, Lucian Georgescu was 
also in charge of branding the city Sibiu and that the MAE campaign wants to be a synergy between the two. The cost for this campaign was 5 million euro, money which should have been allocated through a Government decision. The consultancy contract with Gav/Scholz \& Friends costed 110,000 euro. The campaign should have consisted in a big live concert and advertising (Marin, 2007).

Medium and long term, the authorities wanted to transform the word "spirit" into a brand, what is "conservative" for the British or "engineer" for Germans, according to Foreign Ministry at the time (Covaci, 2007).

The band elected to hold concerts in Europe to promote "fabulous and spiritual" Romania was Damian Draghici and Brothers, who were singing gypsy music.

Three months later after starting this campaign, the new minister of Foreign Affairs, Adrian Cioroianu did not to allocate 5 million euros for this campaign. The concept was abandoned.

It had no website and no evaluation.

I consider irrelevant how the number of foreign tourists raised from $1,429,911$ in 2005 to $1,440,957$ in 2007 after this campaign, because practically it was just a concept not applied in the end because of the lack of budget.

Regarding the tone coverage of media, this was negative and controversial. The concept was considered inappropriate to define the Romanian people, so out of 50 Romanian articles about this topic, 48 were critical and ironical. The international media did not treat this subject at all, so it had no impact at international level.

\section{Romania, Land of Choice}

Agent. In 2009, Ministry of Tourism headed by Minister Elena Udrea launched the campaign Romania, Land of choice. It was part of the project "Creating a positive image of Romania as a tourist destination by defining and promoting the national tourism brand" (Stan, 2013), project funded with 75 million euro allocated through the Regional Operational Program, Axis 5, 2007-2013.

The purpose of this campaign was to increase the number of foreign tourists coming to Romania of at least $10 \%$ the year following the campaign (Rhn, 2009).

It is very difficult to estimate what was the exact cost of this campaign, but certainly a few million euro.

Description. The campaign consisted in broadcasting commercial videos on the media facade of Cocor Media Channer (former store Cocor from Bucharest) for a week, but also on tv channels, Eurosport and CNN.

The endorsers of this campaign were the most important athletes Romania ever had: Nadia Comaneci, Gheorghe Hagi and Ilie Nastase. The tv spots were broadcasted for five months, 550 time on Eurosport, 475 times on Eurosport and 529 times on CNN. For Eurosport, the minister paid 1.2 million euro and 400,000 euro for CNN. The fees for the three stars and the spot production was paid by BRD, Group Societe Generale which already had a contract with them (Pascu, 2009). 
Launching this campaign tool place in front of the City hall of Paris, where it was organized a show with traditional Romanian music and dances. A tennis court was also arranged for a tennis exhibition match between Ilie Nastase and Peter McNamara. Elena Udrea said it costed 88,000 euro.

The campaign might have had a website, but today, everything that remained from this campaign is this portal (www.landofchoice.ro) which is active, but it represents a collection of funny pictures that are not necessarily from Romania. It is not known who the owner of it is. What is known is that Romania, land of choice was registered at OSIM (State Office for Inventions and Trademarks) by a person who had nothing to do with this campaign, which means that if he wants he can demand compensation, because his slogan was used in commercials without his permission.

Minister of Tourism, Elena Udrea did not publish any evaluation of the campaign, but she said that brand Romania will be launched later, after an international auction where prestigious PR agencies will apply in order to promote Romania.

The year following the campaign, the number of foreign tourists did not increase at all, but decreased. In 2008 there were 1,465,891 foreign tourists and in 2010 1,346,343 who spent 3,723,400,432 lei (INSSE, 2017).

From the tone coverage of media perspective, it had rather a neutral tone. The events were presented without critics or appreciation. From 50 Romanian articles 38 were neutral, 3 positive and 9 negative.

In the international media, it was very difficult to find articles about the event, but all 29 had neutral tone.

\section{Explore the Carpathian Garden}

Agent. In 2010, during the World Expo from Shanghai, the Ministry of Tourism and Development, under the leadership of Elena Udrea, together with Romanian sports legends Nadia Comaneci, Ilie Nastase and Gheorghe Hagi launched the most controversial and expensive branding campaign Romania ever had - Explore the Carpathian Garden.

The purpose of this campaign was to improve Romania's image abroad and to double the numbers of tourists by 2013.

The cost was than 56 de millions de euro and the money were spent between 2010-2012. Before the campaign, a study it was undertaken to discover what Romanian consider the most

Description. Romania's tourism brand was created by a Spanish agency, THR - THS based on a market study carried on in Romania and in the eight most important markets, which could supply tourists for the country: Germany, UK, Italy, Russia, Austria, US, France and Hungary.

The study revealed Romania's most competitive six touristic products: the cultural circuits, the nature, the rural areas, the city breaks, the adventure tourism and the wellness tourism (Romania Insider, 2010). 
Designing the brand has cost 900,000 euro and the originally of it became a debate subject not only in Romania, but also in the international media. The graphic element was a leaf and journalists said that it could have been bought from the Internet at a price of 250 de euro (Expres Magazin, 2010). Branding campaign Explore the Carpathian Garden has consisted in Romania's participation in various fairs in the world, the realization of advertising inserts in catalogs sights of major tour German operators German, and 200,000 euro advertising on TV channels, TVR and Realitatea TV.

The campaign had a website, which is still active (www.romania.travel/ro) and gives relevant information about the country, but if you wanted to look for details about this, in march last year, Explore the Carpathian garden was a gardener's website which had nothing to do in Romania (www.carpathiangarden.com). The website in now for sale for 3,195 dollars.

More than 2.5 million euro were spent for promoting the logo of the nation branding campaign during Lucian Bute's box matches. Other 5 million euros were allocated in advertising on $3 \mathrm{TV}$ international channels, CNN, Euronews and Eurosport (Stan, 2013).

Like all the other initiators of branding Romania, The Minister of Tourism did not publish a relevant evaluation in order to measure the impact of the campaign.

The number of foreign tourists did not double, but it increased from 1,346,343 foreign tourists in 2010 to 1,5 million in 2012 to 1.71 million in 2013 who spent 4,79 billion RON (INSSE, 2017).

This nation branding campaign ended with more criminal cases for corruption. So, from the tone of coverage of media, internal and international, the tone for this campaign was negative dominated by criticism once for the graphic element/ logo and money spent for it and also on corruption scandal.

Table 1. Comparative analysis of 5 of the most relevant Romania branding campaigns based on 9 indicators

\begin{tabular}{|c|c|c|c|c|c|}
\hline $\begin{array}{l}\text { Nation } \\
\text { branding } \\
\text { campaign } \\
\text { (Year) }\end{array}$ & $\begin{array}{l}\text { Eternal and } \\
\text { Fascinating } \\
\text { Romania } \\
\text { (1996) }\end{array}$ & $\begin{array}{l}\text { Romania, } \\
\text { Simply } \\
\text { Surprising } \\
(2001)\end{array}$ & $\begin{array}{l}\text { Fabulospi } \\
\text { rit (2006) }\end{array}$ & $\begin{array}{l}\text { Romania, } \\
\text { Land } \\
\text { Choice } \\
(2009)\end{array}$ & $\begin{array}{l}\text { Explore the } \\
\text { Carpathian } \\
\text { Garden }(2010)\end{array}$ \\
\hline Agent & $\begin{array}{l}\text { Romanian } \\
\text { Government } \\
\text { with the } \\
\text { support of } \\
\text { the } \\
\text { Romanian } \\
\text { Presidency }\end{array}$ & $\begin{array}{l}\text { Directorate } \\
\text { General for } \\
\text { Tourism } \\
\text { Promotion }\end{array}$ & $\begin{array}{c}\text { Minister of } \\
\text { Foreign } \\
\text { Affairs }\end{array}$ & $\begin{array}{l}\text { Ministry of } \\
\text { Tourism }\end{array}$ & $\begin{array}{c}\text { Ministry of } \\
\text { Tourism }\end{array}$ \\
\hline Purpose & $\begin{array}{l}\text { change/imp } \\
\text { rove } \\
\text { Romania's } \\
\text { image } \\
\text { abroad }\end{array}$ & $\begin{array}{l}\text { Attract } \\
\text { foreign } \\
\text { tourist }\end{array}$ & $\begin{array}{c}\text { Shape the } \\
\text { image of } \\
\text { Romania } \\
\text { as a new } \\
\text { EU } \\
\text { member }\end{array}$ & $\begin{array}{c}\text { Creating a } \\
\text { positive image } \\
\text { of Romania as } \\
\text { a tourist } \\
\text { destination }\end{array}$ & $\begin{array}{c}\text { Improve } \\
\text { Romania's image } \\
\text { abroad and to } \\
\text { double the } \\
\text { numbers of } \\
\text { tourists by } 2013\end{array}$ \\
\hline
\end{tabular}




\begin{tabular}{|c|c|c|c|c|c|}
\hline Cost (euro) & $5.61 \mathrm{mil}$. & $18.69 \mathrm{mil}$. & 110,000 & $<2$ mil. & 56 mil. \\
\hline Website & No & No & No & $\begin{array}{l}\text { Maybe but not } \\
\text { active in } \\
\text { present }\end{array}$ & $\begin{array}{c}\text { www.romania.tr } \\
\text { avel/ro }\end{array}$ \\
\hline Evaluation & No & No & $\begin{array}{l}\text { No/Aband } \\
\text { oned }\end{array}$ & No & Not relevant \\
\hline $\begin{array}{l}\text { Number of } \\
\text { foreign } \\
\text { tourists } \\
\text { before the } \\
\text { campaign }\end{array}$ & 856,136 & 867,024 & $1,429,911$ & $1,465,891$ & $1,346,343$ \\
\hline $\begin{array}{l}\text { Number of } \\
\text { foreign } \\
\text { tourists } \\
\text { following } \\
\text { the } \\
\text { campaign } \\
\end{array}$ & 832,775 & $1.429,911$ & $1,440,957$ & $1,346,343$ & $1,500,000$ \\
\hline $\begin{array}{l}\text { Tone of } \\
\text { coverage } \\
\text { (national } \\
\text { media) }\end{array}$ & Negative & Negative & Negative & Neutral & Negative \\
\hline $\begin{array}{l}\text { Tone of } \\
\text { coverage } \\
\text { (internation } \\
\text { al media) }\end{array}$ & Negative & Negative & Negative & Neutral & Negative \\
\hline
\end{tabular}

Source: Authors' own research.

\section{Results and discussions}

\section{Building Romania's brand}

Based on the comparative analysis there are a number of strengths and weaknesses, regarding the way Romania's branding campaigns were built, presented in Table 2 . Also, a number of opportunities and threats withdrawn from a short analyze of the international context completes Table 2 .

Table 2. SWOT analysis for Romania's branding campaign building

\begin{tabular}{|c|c|}
\hline Strengths & Weaknesses \\
\hline $\begin{array}{l}\text { Important Romanian public } \\
\text { institutions realized the importance } \\
\text { of nation branding and invested in } \\
\text { image campaigns; }\end{array}$ & $\begin{array}{l}\text { Lack of relevant studies which } \\
\text { should involve all actors when } \\
\text { building the campaign }\end{array}$ \\
- $\begin{array}{l}\text { Special budget allocated for nation } \\
\text { branding campaigns; }\end{array}$ & $\begin{array}{l}\text { Lack of evaluation after Romania's } \\
\text { branding campaigns in order to } \\
\text { identify strengths and weaknesses }\end{array}$ \\
- Increasing number of foreign \\
$\begin{array}{l}\text { tourists starting 1996; } \\
\text { Positive mentions of Romania in the } \\
\text { international media/tv through } \\
\text { advertising; }\end{array}$
\end{tabular}




\begin{tabular}{|c|c|}
\hline & $\begin{array}{l}\text { - Lack of online promotion; } \\
\text { - Lack of interesting PR stories which } \\
\text { should attract media's attention; } \\
\text { Total lack of coordination between } \\
\text { the institutions and other actors } \\
\text { involved in the process; } \\
\text { - Absence of connection between the } \\
\text { nation branding campaign and the } \\
\text { citizens. }\end{array}$ \\
\hline Opportunities & Threats \\
\hline $\begin{array}{ll}\text { - } & \text { Romania EU member; } \\
\text { - } & \text { Romania NATO member; } \\
\text { - } & \text { Romania safe country in the context } \\
& \text { of terrorist attacks; } \\
\text { - } & \text { Romania IT business hub; } \\
\text { - } & \text { Romania, safe holydays, beautiful } \\
& \text { country. }\end{array}$ & $\begin{array}{l}\text { - Intensification of globalization which } \\
\text { favors developed countries with } \\
\text { advanced economies; } \\
\text { Too many international articles } \\
\text { based on Romanian corruption - risk } \\
\text { of branding Romania as corrupt } \\
\text { country; } \\
\text { - Politic and economic instability } \\
\text { which creates an unpredictable } \\
\text { environment. }\end{array}$ \\
\hline
\end{tabular}

Source: Authors' own research.

Table 2 shows that nation branding campaigns are necessary and can constitute added value for country image. But at the same time, analyzing five of them in comparison, I can conclude that there is a lack of coordination between the actors which should have been involved in the process and that there are missing important steps necessary for a successful nation branding campaign.

\section{Conclusions}

Comparing the five campaigns presented above, it is can be concluded that they have many similarities and are based on same principles and criteria. All five were initiated by public institutions, three by Minister of Tourism (Romania, Simply Surprising; Romania, Land of Choice; Explore the Carpathian Garden), one by Government (Eternal and Fascinating Romania) and one by the Minister of Foreign Affairs (Fabulospirit). But Fabulospirit was abandoned just before its start. All five had the main purpose of improving Romania's image and then to increase the number of tourists. And none took in consideration the mistakes from the previous one.

"You cannot change public perception through advertising. Change the way people think finding the truth, finding an idea to put that truth and taking him out" (Olins, 2007, p. 60). None of the campaigns had any evaluation after its final and only "Explore the Carpathian Garden" undertook a study before building the campaign in order to find out on what values should base the concept, the "truth" explained by Olins above.

Citizens' perception about their own country is reflected in the country's image both internally and externally. Anholt noted that countries where people have 
a good image about their country can develop a very strong country brand. It argues that if a country's citizens do not believe in the power of their country, then they will not be able to persuade others to believe (Gandul, 2007). To build a strong country brand, first it must be crept in the minds of citizens, otherwise any attempt at branding the country will result in failure.

This important connection between the people and the campaign missed almost completely from all the attempts of branding Romania, which can be observed from the descriptions of the campaigns. One of the most serious problems was the fact that citizens were not involved at all in the campaigns. So, Romania's brand should have been created by the specialists together with the people and promoted involving the people.

Anholt (2007) considers that nation branding management should be a part of national policy and not a separate campaign of government program or a separate campaign of economic growth plan. In Romania, all five attempts of branding were rather independent campaigns without coordination and connection between the actors which should be part of the process.

So, in conclusion, in order to build a successful nation branding campaign, first it should be found the concept, the truth Olins(2007) was mentioning, involving all the citizens and all the other actors (Government, industry, media, people, opinion formers, specialists in branding). Then, the concept must be integrated in country program elaborated by the Government. This one should be assumed and continued even if Government changes, because a permanent reform stops solid construction.

Identifying an existent natural identity (Nicolescu et al., 2008) could be useful for country branding and sometimes identifying facts in a regional identity in our case European identity can be very relevant (Diaconescu et al., 2007).

The five campaigns analyzed above show this lack of connection and solid construction necessary for a successful branding process. Each one of them revealed a new beginning every time and in the end none managed to accomplish the assumed objective. And at the same time none was able to transmit a strong and durable message abroad to improve Romania's image. So even if, it was important and benefic that Romanian institutions realized that the country needs nation branding campaigns in order to improve its image, the actions undertaken had minimum positive impact.

All campaigns ended with corruption scandals which were intensely publicized, therefore this message was stronger than the one the campaign had.

As a final conclusion of this paper, it can be said that Romanian institutions should start the branding campaign first inside the country and then promoted outside, because if the Romanian citizens do not believe in Romania's brand, then foreigners will not believe either.

\section{References}


9am, (2007), "Fabulospirit - 5.000.000 de euro". Retrieved from www.9am.ro/stirirevista-presei/Actualitate/56321/Fabulospirit-5-000-000-deeuro.html\#ixzz3yWQEZolL.

Amin, A. and Thrift, N. (1994), Living in the global. Oxford, Oxford University Press.

Andrei, A. (2016), "Impact of nation branding campaigns on country image: Germany vs. Brazil”, Cactus Tourism Journal, Vol. 14, No. 2, 2016, pp. 25-32.

Anholt, S. (2007). Competitive identity, New York: Palgrave Macmillan.

Anholt, S. (2009), "The media and national image", Place Branding and Public Diplomacy, Vol. 5, No. 3, pp. 169-179.

Anholt, S. (2010). Places: Identity, image, and reputation. New York: Palgrave Macmillan.

Aronczyk, M. (2013). Branding the nation - The global business of national identity, New York: Oxford University Press;

Capital (2004), "Romania, "mereu surprinzatoare" cand isi liciteaza imaginea", Retrieved from www.capital.ro/romania-mereu-surprinzatoare-cand-isiliciteaza-imaginea-16023.html.

Diaconescu, M., Nicolescu, L. and Panzaru, F. (2007), "Romania within the EU: opportunities, requirements and perspectives", Sibiu Conference Proceedings, Vol. 1, 2007, pp. 135-141;

Dinnie, K. (2008). Nation branding: Concepts, issues, practice. Oxford: Elsevier.

Dolea, A. and Tarus, A. (2009). Branding Romania. Cum (ne)promovam imaginea de tara. Bucuresti, Curtea Veche.

Dolea, A. (2015). Twenty years of (re)branding post-communist Romania, Iasi, Institutul European.

Expres Magazin (2010). Frunza din brandul de ţară poate fi cumpărată de pe internet cu 250 de euro. „Grădina” Elenei Udrea costă însă 75 de milioane de euro. De la Shanghai, Udrea se ceartă cu ziariştii. Retrieved from www.expresmagazin.ro/frunza-din-brandul-de-ar-poate-fi-cumprat-de-peinternet-cu-250-de-euro-aezgrdinaae\%C2\%9D-elenei-udrea-cost-ns-75-demilioane-de-euro-de-la-shanghai.

Gandul, (2007). Wally Olins ar accepta sa construiasca "brandul de tara" pentru Romania. Retrieved from http://www.gandul.info/magazin/wally-olins-araccepta-sa-construiasca-quot-brandul-de-tara-quot-pentru-romania-280392.

Howard, J. and Sheth, J.N. (1968), Theory of buyer behavior, New York: J. Wiley \& Sons.

Institutul National de Statistica, INSSE (2017). Retrieved from www.insse.ro.

Lovell, N. (1998). Introduction: belonging in need of emplacement?, London, Routledge.

Lustig, M.W. and Koester, J. (1999), Intercultural competence: Interpersonal communication across culture, Longman: New York.

Kaneva, N. (2012). Branding post-Communists nations. New York: Routledge.

Kaneva, N. and Popescu, D. (2011). National identity lite: Nation branding in postcommunist Romania and Bulgaria. INTERNATIONAL journal of CULTURAL studies, Vol. 14, No. 2, pp.191-207. 
Lupan, M. (2009). Globalizarea economiei. Retrieved from www.seap.usv.ro/ $\sim$ ro/cursuri/ECTS/ECTS_GE.pdf.

Meyer, B. and Gerschiere, P. (1999). Globalization and identity: Dialects of flow and closure, Oxford, Blackwell.

Nicolescu, L., Cojanu, V., Popescu, A. and Drăghici, A. (2007), Developing country branding: a key factor for international competitiveness, Bucharest, Editura SNSPA, pp. 285-291.

Nicolescu, N. (2008), Imaginea României sub lupă! Branding şi rebranding de ţară, Bucuresti, Editura ASE.

Nicolescu, N., Paun, C.,Popescu, A.I., Draghici, A. and Pinzaru, F. (2007), "National identity an essential element for country branding. The case of Romania", Review of Management and Economical Engineering, Vol. 6, No. 6, pp. 78-83.

Nicolescu, N., Paun, C., Popescu, A. and Draghici, A. (2008), "Romania trying to be an European brand", Management \& Marketing. Challenges for the Knowledge Society, Vol. 3, No. 1, pp. 61-72.

Olins, W. (1999) Trading identities: Why countries and companies are taking each other's' roles, London, The Foreign Policy Centre.

Olins, W. (2003). On brand. London, Thames and Hudson.

Olins, W. (2008), The brand handbook, London, Thames and Hudson.

Padurariu, C. (2015, June 12), "Cum n-au mâncat est-europenii lebedele reginei la Londra. Istoria unui fals jurnalistic grosolan, produs în 2003 de tabloidul britanic The Sun". Retrieved from adevarul.ro/locale/iasi/mitulest-europenilor-mancat-lebedele-reginei-londra-istoria-unui-falsjurnalistic-grosolan-produs-2003-tabloidul-britanic-the-sun1_5579981ecfbe376e352e838e/index.html.

Pascu, R. (2009, August 6), "'The Land of Choice' pe ecrane....". Retrieved from razvanpascu.ro/2009/08/06/the-land-of-choice-pe-ecran.

Romania Insider (2010, July 29), "Romania launches “Explore the Carpathian garden” slogan, public doubts logo uniqueness". Retrieved from www.romania-insider.com/ romania-launches-tourism-campaign-under-explore-the-carpathian-garden-slogan.

Surcel, V. (2006, December), "Bibliofilie scumpa - o carte cat un munte de bani”. Retrieved from jurnalul.ro/special-jurnalul/bibliofilie-scumpa-o-carte-catun-munte-de-bani-6628.html.

Sepi, A. (2013, October), "Nation branding: The case of Romania". Retrieved from www.culturaldiplomacy.org/pdf/case-studies/Andreea_Sepi__Nation_Branding_-_The_Case_of_Romania.pdf.

Sorin, C. (2015, September 10), "Neagu Djuvara: 99 de ganduri si obsesii”. Retrieved from www.qmagazine.ro/neagu-djuvara-99-de-ganduri-\%C5\%9Fiobsesii_271177.html.

Stan, E. (2013, February 27), “Elena Udrea a produs cea mai scumpă frunză din lume. Realizarea şi promovarea brandului turistic au costat peste 20 de milioane de euro". Retrieved from jurnalul.ro/special-jurnalul/anchete/cea- 
mai-scumpa-frunza-din-lume-realizarea-si-promovarea-branduluituristic-au-costat- peste-20-de-milioane-de-euro-637896.html.

Verdery, K. (1991), National ideology under Socialism: Identity and cultural politics in Ceausescu's Romania. Berkeley: University of California Press. 